\title{
The Use of the Six English Tenses in Students' Daily Conversation
}

\author{
${ }^{1}$ Maulana Yusuf Aditya, and ${ }^{2}$ Chairuddin \\ ${ }^{1}$ STKIP PGRI Bangkalan, Bangkalan \\ ${ }^{2}$ STKIP PGRI Bangkalan, Bangkalan \\ (aditya@ @stkippgri-bkl.ac.id)
}

Article History: Submitted November $17^{\text {th }}, 2020$; Accepted February 28 ${ }^{\text {th }}, 2021$; Published March $2^{\text {nd }}, 2021$

\begin{abstract}
For English learners, there are important aspects to consider such as vocabulary, pronunciation and grammar to master their speaking skills. Speaking is used to express people's ideas and feelings in daily life or to communicate with others both personal talks and transactional conversation. The objective of the study is to figure out how the students of SMKN 2 Bangkalan can use the six English tenses in daily conversation. The research was done within two weeks starting from $22^{\text {th }}$ April to $06^{\text {th }}$ May 2019. Observation and interview were performed to collect the data. Observation was made to see what was going on in the class, focusing on the students' conversation. On the other hand, Interview was carried out to know the students' problems in using the correct tenses in conversation, and to find out how the students solve the problems. The observation shows that in using the six English tenses, the students likely found it hard to apply the correct tenses in the conversation with their friends and the teacher. The students tended to use one tense in all situations and the tense mostly used was the simple present one. From the interview, it is found that the students do not really understand what tenses are, either the meaning or the uses.
\end{abstract}

Keywords: daily conversation, tenses, observation, interview, contexts of situation

Abstrak. Bagi pembelajar Bahasa Ingggris, terdapat aspek penting seperti kosakata,
pengucapan dan tatabahasa yang harus diperhatikan untuk meningkatkan
kemampuan berbahasa Inggrisnya. Kemampuan berbicara khususnya digunakan
untuk menyampaikann semua yang ada dalam benak kita seperti misalnya ide dan
perasaan dalam kehidupan sehari-hari, baik itu berupa perkataan pribadi atau pun
percakapan transaksional. Tujuan utama penelitian ini adalah untuk mengetahui
bagaimana murid dapat menggunakan enam kala (tenses) dalam percakapan sehari-
hari sesuai dengan kontek situasi, di SMKN 2 Bangkalan. Penelitian dilakukan selama
2 minggu dimulai tanggal 22 April s/d O6 Mei 2019. Penelitian dilakukan dengan 2
langkah seperti observasi dan wawancara. Observasi dilakukan untuk mengetahui
yang terjadi dalam selama proses pembelajaran danfokus pada cara murid bercakap.
Wawancara dilakukan oleh peneliti untuk mengetahui permasalahan pada murid
dalam menggunakan tenses yang benar dan bagaimana murid mengatasi masalah
penggunaan kala yang benar tersebut. Dari hasil observasi dapat diketahui bahwa
penggunaan enam kala dalam percakapan sehari-hari dari murid adalah buruk,
mereka tidak bisa mengaplikasikan kala yang sesuai dalam percakapan, baik dengan
teman dan guru. Mereka cenderung menggunakan satu kala dalam percakapandalam
konteks situasi yang berbeda dan tense yang digunakan adalah Simple Present Tense.

Kata kunci: percakapan, kala, observasi, wawancara, konteks situasi 


\section{INTRODUCTION}

English is a language that the learners must understand four skills to master it. Sometimes the students do not know what steps to take to improve their skills in learning English. There are four skills in learning English, such as speaking, listening, reading and writing. According to Louma (2004) speaking skill is an important part of the curriculum in language teaching, and this makes oral mastery an important object of assessment as well. Assessing speaking is challenging. However, there are many factors that influence people's interest of how well someone can speak the language. It is also because the researchers are expecting the test scores to be accurate and appropriate for the research's goals.

Here the researchers state that the most important skill in mastering English language much earlier is speaking. It is important to acknowledge because from speaking people will learn many things about English like correct grammars, correct choice of words, good pronunciation and others. Speaking makes people listen and talk back to respond. They hear how native speakers use language, so that they can learn more quickly using the language in meaningful ways. This makes it easier to remember and to use correctly. The students can gradually correct every mistake by themselves to achieve good speaking skills. After mastering speaking, hopefully the students can develop other skills to complete their understanding about English language.

According to Pardiyono (2004) one of the most confusing terms for many English learners especially those who are studying at High Schools, is whether the students have to master grammar first or the acquaintance of speaking skill later or vice versa. It is the speaking skill first that must be acquired and then the mastery of grammar soon afterward. Speaking is an activity used by someone to communicate with others.

Can the students learn to speak without grammar? Can the students learn grammar without speaking? Is there a special grammar of speech? What's the best way to learn speaking? Grammar is very important in speaking and if a conversation is full of grammatical errors, the messages will not get across successfully. Studying grammar rules will certainly help the students speak more accurately. This advice sheet will shed light on how to learn grammar for speaking systematically. It will also inform us of what other things are important to develop accuracy in speaking English. This refers to what learners normally mean by conversation and describe interaction which serves a primarily social function. When the students meet, the students exchange greetings, engage in small talks and chit chats. The focus is more on the speakers and how the students wish to present themselves to each other by exchanging ideas in their casual or more formal conversations depending on the circumstance and their nature has been well described by Brown (2000) in (Khoiriyah 10:2011).

It is not really easy to speak English well because sometimes the students are still in doubt about using the grammar in every conversation. Even worse the students find it hard to use the right grammar in daily conversation among the students or between the teacher and students in the classroom. That is the reason why the researchers want to figure out how good the students apply the six English tenses in their daily conversation such as telling a story, giving opinion or information, and their hope in the future time. Albert Val man said, "The ability to speak a foreign language is without doubt the most highly prized language skills, and rightly. “ 
From the explanation above, the researchers are determined to find the real facts of how many tenses used the most by the students. Sometimes the students are having different reasons applying the tenses or the students do not know what tenses to use in their daily conversation. It shows that the students understand the tenses but they are reluctant to make use of the correct tenses, the students understand but they are confused or the students do not understand at all. The researchers are trying to give some easy ways in using the six English tenses in their conversation where the students think that it is difficult. Besides that, solutions are also given for their speaking problems, so that the students find it easy to make a good conversation with the correct tenses. The researchers are also trying to find out more effective designs for the students to acquire correct English's tenses in daily conversations. According to Pardiyono (2004) to convey the learning problems mentioned above by which the students of high school are not only expected to be good at grammar but also good at speaking.

\section{METHOD}

Research designs are plans and the procedures for research that span the decisions from broad assumptions to detailed techniques of data collection and analysis. This plan involved several decisions, and the students needed not to be taken in the order in which the students make sense to me and the order of their presentation here. The overall decision involves which design should be used to study a topic. Informing this decision should be the worldview assumptions the researchers bring to the study procedures of inquiry (called strategies) and specific techniques of data collection, analysis, and interpretation. The selection of a research design is also based on the nature of the research problem or issue being addressed, the researchers' personal experiences, and the audiences for the study. The researchers used a descriptive qualitative design to describe and obtain data from the research and other words to get validity and reliability. Qualitative research is a means for exploring and understanding the meaning individuals or groups ascribe to a social or human problem (Sugiono, 2011).

Subject is an individual who participates in research study or is someone from data collection (Richards, 2002). This study is conducted at SMKN 2 Bangkalan which is located at Kabupaten Bangkalan-Madura. The subject of the research is the students at tenth grade of SMKN 2 Bangkalan. There are 34 students of the tenth grade. The object of the research is the use of the six English tenses in students' daily conversation.

Since there were many advantages from observation technique, interview technique and documentation as additional references, the researchers used all of those techniques in data collection technique in conducting the research.

Bogdan said "In most traditional of qualitative research, the phrase personal document is used broadly to refer to any first person narrative produced by an individual who describes his or her own action, experience and belief. Photograph provide strikingly descriptive data, are often used to understand the subjective and is product are frequently, analyzed inductive. It means that the researchers collected all the things that have to do with their research, such as note-taking, images or voices/video recorders to confirm the data. Documentation is an additional evidence to make sure the results from the qualitative research. The documentations will be a description of the observant. 
Bogdan clarified "if data analysis technique is the process of systematically searching and arranging the interview transcripts, field notes, and other materials that you accumulate to increase your own understanding of them and enable you to present what you discover each other".

The first part, the researchers paid the school a visit where observation was going to be conducted. Before conducting the observation, the researchers are talking it over to the Head Master of SMKN 2 Bangkalan, along with the English teacher. The purpose is to ask for permission to do observation. The researchers also explained what to do in the classroom during the teaching-learning process. Here, the researchers are observing the students' activity to focus more on their speaking ability, particularly in using the six English tenses in daily conversations. Since the observation has been conducted, the researchers are doing an interview to get more data about the problems that the students have and how to solve the problems.

\section{RESULTS AND DISCUSSION}

The researchers conducted the observation to know the students of the tenth grade students of SMKN 2 Bangkalan in using the six English tenses in daily conversation. The observation is also used to stimulate the students to make a little conversation. For this purpose, the teacher is trying to create a small conversation about greeting, self-introduction and discussing over simple topics. There is also a private conversation between the students and the teacher with the hope that the students will respond to the teacher without hesitation.

It was 10.30 a.m in the morning when the researchers entered the classroom to meet the students. As always, prior to the discussion over the subject, the teacher performs a greeting to the students and asks also about their state of being. For additional information, the interaction was directed using a bilingual language during the learning activity; 65\% Indonesian and 35\% English. After five minutes passed by, the researchers did not find anything wrong with the student's conversation meaning that there was good so far in greeting. The students used the correct tense, that is simple present tense. After greeting the students, the teacher introduced the researchers to them and gave some explanations about our presence in that class. When the introduction was happening, the students gave some questions for the researchers about their profile. Some of the questions are" Where are you live?" and "What you single?". The students did not understand to ask a question with the WH-questions and they were still confused about the use of simple present tense

In collecting the data from observation technique, the teacher made an effort to communicate with the students. The teacher found it difficult to get the students' responses to start a conversation. The researchers could see if most of the students were confused, silent, and making a riot behind. The researchers then had to be more attractive to catch their attention by delivering hot issues in the present time to talk about. It was about the advantages of facebook and blackberry messenger. With this issue, the teacher successfully made an intensive conversation and as a result the students give their response. In the end, the researchers got what they wanted, like the usage of the six English tenses in the conversations. That was a simple topic and the students needed to give a reason about why the students could make it, what do the students make it for? Unfortunately, at that moment almost of all students was bad in English usage whereas researchers hopefully the students did it well, the most complicated moment of them just being silent or making a riot behind, even there some of them used English to speak because the teacher forced to speak English 
and combined with Indonesian. As result the use of the six English tenses was bad, for instance when the teacher asked about "Why did you make a facebook?" Students' answer was "I make because I need", another conversation was "why do you not buy a blackberry?" Students 'answer was "I am not have money". The students tended to apply "simple present" in all conversations, even it was supposed in different contexts of each situation.

It was on 29th of April 2019 that the first section was made to put the observation into practice. Everything had to be prepared before conducting an observation. It was at 10 a.m. in the morning, the researchers were prepared to do the observation before the class started at 10.30 a.m. When starting the observation, the teacher was teaching an accounting lesson. She then called out upon the researchers and the students together to meet up in the teacher's room. The students were discussing over some subject matters while the researchers were observing their discussion.

The researchers' purpose is to observe the ambiance during the learning process and to take some notes of what is going on in the classroom. The main target of this observation activity is to find out all about the students' speaking ability especially in using the six English tenses. Most of the students' ability in using the six English tenses was not in the proper use of certain contexts. Here are some facts that the students' ability to use the six English tenses was bad, for instance when the teacher asked about Why did you make a facebook? Student's answer was I make because I need, other conversation was why do you not buy a Blackberry? Student's answer was I am not have money. The students mostly used simple present tense in all utterances ignoring the correct grammars used in different contexts of situation.

The conversation has been running for 1 hour and every student is still enthusiastic to take part in the conversation. They all enjoy talking in English although the allocated time has almost been running out. The teacher was sitting next to the students who have good command in English to make further conversation about some future plans such as After finishing your study from this school, what will you do? One student answered I find a job and I study at the University, Where did you go last time in your holiday? and the answer was I go to Surabaya. Another question was Today is an English lesson, have you studied it before? and the answer was Yes, I study. From the answers, it shows that the students still have problem using the correct grammar of English in responding to the questions with various tenses. They always used Simple Present Tense to answer all questions that require answers in different tenses.

During the observation section, the researchers obtained insightful information why the students looked so much in doubt to speak English. The researchers also concluded that the mastery of grammar in the conversation was insufficient enough. The teacher also went on to say that she had to try hard to get the students' attention in class.

Meanwhile, the interview section got started at 08.30 a.m. on Friday, 3th of May 2019. After getting permission from the teacher who has just finished teaching the class, the researchers directly began to ask the students as respondent some questions in relation to the use of the six English tenses in daily conversations.

The questions are as follows:

1. What are English tenses in your opinion?

2. How many tenses do you know? 
3. What tenses are often used and seldom used in conversation?

4. Are tenses important for your conversation?

5. Which tenses are difficult and easy for you?

6. What problems do you have when studying English tenses?

7. How do you solve your problems to understand English tenses?

From the interview, the researchers found much information using two languages; English and Indonesian. The interview was performed to know the shortages of the students in their daily conversation. The information from the interview was also used to confirm and complete the missing information displayed from the observation. Doing an interview with the students about English tenses proves that some students did not really understand the tenses at all. Even after the researchers gave some formula of how to learn the six English tenses effortlessly, the students did not respond it in positive manners. They said that they just knew it from us. There were 13 students out of 34 students in that class who have already known well the English tenses and how to apply them in daily conversations. However, the students as second language learners in general claim that they still have problem using the correct six English tenses in conversations.

Based on the data collection from interview, it shows that the students have some problems using the correct English tenses in daily conversations as follows:

1. The students do not understand well what tenses are.

2. The students do not know the number of English tenses thoroughly, and are unable to memorize the formula from the tenses' uses.

3. The students do not master the commonly-used tenses in the conversation and are unable to memorize the verb alternation of each tense.

4. The students always responded by saying 'YES' but actually they knew nothing about the different uses of each tense in a correct way.

5. The most rarely-used tenses are simple past and present perfect tenses. The most frequently-used tense is simple present tense

6. The students have lower motivation in learning English and they seem reluctant to learn the correct uses of English tenses.

There are some other facts that had to be taken into account by the researchers. It concerns the problems that the students have to understand English tenses. Here are some suggestions to help the students understand better about using the six English tenses in daily conversations:

1. The students should study harder.

2. The students should learn more deeply the formula of tenses and other supporting parts in the correct use of tenses.

3. The students should encourage themselves to learn English tenses in other places outside school, like in English Courses or You tube videos.

4. The students should learn more about tenses by inviting a private teacher.

5. The students should have more times to practice using the tenses in conversation.

From the data above, most of the students did not understand the tenses equally well. The students were identified to find it difficult when answering the questions about English tenses. Further, it is found that the students mostly have lack of knowledge about regular and irregular verbs. They knew only a little about the use of verb forms in different tenses.

The observation data taken at the Accounting class of the tenth grade of SMKN 2 Bangkalan show that there are quite a few unforeseen mistakes found during the conversation session 
between the students and the English teacher. The main focus of the researchers in this research was on the use of tenses itself by the students, however the researchers found out that the students clearly have problems with their speaking skills. They have very few vocabularies and lack of knowledge about using the six English tenses, which in fact are commonly used in daily conversations. Beside that, the students were not taking an active part in class, they chose to wait to talk only when they were asked to. These phenomena may affect the students' understanding of English tenses in the long run. It also explains why the students always used the simple present tense in responding the questions in various tenses.

Another evidence that the researchers found in that class was when the teacher tried to communicate with the students by using English, they gave no responses at all. Surprisingly, when the teacher spoke in Bahasa Indonesia, the students responded actively. In another situation, the students were not even showing any interest to talk about some topics of discussion with their classmates in English. Only a few kept silent and were not interested to converse among them. Only 13 out of 34 students could speak English well. However, the researchers realized that the students had difficulty in using the six English tenses when the tenses were made in various contexts. From this research, it is expected that the students would be able to speak English well especially in using the six English tenses. They should know how to use the correct tense in a sentence. When speaking, the students were no longer accustomed to using Simple Present Tense. In short, most of the students' ability in using the six English tenses was still low. In normal conversation, people tend to start it with greetings, small talks, information exchanges, and some other important issues that make conversation run well. In that case, the students followed everything what the researchers said. The students wish they could get closer to each other to establish a comfortable zone of interaction. It is crystal clear that they should be able to use the six English tenses in conversations. When greeting, they should definitely use simple present tense or simple present continuous tense.

In small talks, the speaker and the listener can apply various tenses such as simple present, simple present continuous, simple present perfect and simple future. In recounts, simple past and simple past continuous are mostly used. Misunderstanding will not take place if the students use correct tenses in every interaction. Unfortunately, the statement above is contrast to the real situation in the conversation class where most students used only one tense namely Simple Present Tense. In that particular conversation, there should be various tenses to have been applied. However, there were 13 students who could speak English well and some other students still got confused with the use of what, how and when in making up questions. The researchers also found another reason why the students become lazy, shy, and confused with English tenses when doing a conversation.

All of the weaknesses above are not the reasons why the students cannot speak English fluently or have not enough knowledge to use the six English tenses in conversations. Long before the students are at the tenth grade, they have already been studying English since Elementary or Junior High Schools. Supposedly they must have learned so much more about tenses in English. Another situation is that the curriculum itself has been upgraded repeatedly to become a better one than that in the past. That should be another reason as second language learners (L2) why the students must be able to speak English well in their daily conversation. Based on the findings, the researchers conclude that the students' understanding of using the six English tenses was indeed insufficient and it affects their speaking skills to become fairly poor in practice. 
The researchers found out that there are only 13 out of 34 students who can speak English well and from the 13 students, there are 3 students who can speak English very effortlessly. It is a common fact in learning English or other new languages that the learners must have good mastery in the language aspects thoroughly such as vocabulary, pronunciation and grammar. One of the most important aspects in mastering the grammar is understanding the tenses. English tenses are used to talk about the time when things are spoken. The time varies according to an activity uttered at the moment of speaking. It shows a particular time to explain whether an activity is still going on, already passed, or will take place in some future times. Thus, when studying grammar, the students are, in fact, exploring the world of Applied Linguistics, Morphology and Pragmatics of the language. Without becoming overly technical, grammar investigates language unit functions and how the students are used in a sentence to convey meaning. The "Peanut Gallery," means that the study of nouns, verbs, adjectives, other parts of speech, and their functions are inevitable. This includes how the students convey meaning in communication; reading, listening, writing, or speaking. Grammar deals with morphemes and the word combinations used to form meaning. Then if the teacher and the students are in an interaction, the students should use correct tenses. Otherwise, there will be a misunderstanding for not having the ideas got acrossed.

However, the researchers have shown how the tenses give a contribution to getting ideas across between the two speakers. On the other hand, the English learners as second language claimed that the tenses should not mainly be focused on. This belief will not only cause the students to focus more on grammar when speaking but also it may make the students struggle from thinking a lot about correct grammar. The main point is that teachers should keep the students speaking a lot more and enjoying the atmosphere of English conversation class. As a matter of fact, grammar, along with tenses within, is important to learn. For that reason, the mastery of tenses is crucial and it should not be ignored whatever it takes. There are 16 tenses in total but there are merely six tenses which are commonly used in conversations such as simple present, simple present continuous, simple present perfect, simple past, simple past continuous and simple future tenses. In using the tenses appropriately, students must also learn that the correct use of tenses depends much on their understanding about the time when the action happens. It would be a problem if for example the speaker wants to tell something happening at the moment of speaking and he uses Simple Past Tense instead of Simple Present Continuous Tense. This particular incident occurs frequently in the conversation class where the students seem to ignore the correct use of English tenses.

There are some more weaknesses of the students found from conducting observation and interview in this study. Not only having poor knowledge about English language, but also the students are having inadequate knowledge about using the six tenses in conversation. The following weaknesses are written down below:

1. The students understand a little about using the tenses.

2. The students apprehend a little when to use the correct tenses in sentences.

3. The students only know a little about the formula of each tense and other supporting things in tenses such as verb forms, auxiliary verbs and time signals.

The reasons why the students are so weak in speaking English are:

1. The students never study again in their free time outside school.

2. The students do not have enough chances to speak up in the English class or outside school.

3. The students do not have partners to speak English with 
In one particular occasion, the researchers asked the students about dealing with the problems, and they all exclaimed that they always studied tenses both in school and home. However, from that short answer, it shows that the students still have problems understanding English tenses, although some students came up with their good memory about the verb forms (Regular Verbs and Irregular Verbs), formula of tenses, time signals and auxiliary verbs. On one hand, there are always reasons to believe that the students do not have enough knowledge about tenses. On the other hand, the students must be good at English, especially Speaking skill according to the Lesson Plan. Another problem for the students that prevents them from being good at English is the system applied in the teachinglearning process. This issue has become common among educators that teachers must be creative to always create a good atmosphere in class. They must have a good teaching technique. The technique that keeps the class going from the beginning to the end of the class session. The students indeed need a great passion to learn tenses since one difficult part in learning English grammar is the tenses. There are quite a few things to learn about tenses such as the tense formula, verb forms, auxiliary verbs, time signals etc. Once a teacher gives an unappropiate technique in teaching tenses, the students may lose interest to follow through. It is also expected for the teacher of English to keep the class run well. Hopefully, by using a proper teaching technique, not one single student gets bored from the English class and learn everything equally well.

There are examples of great techniques in teaching tenses and those are recomended for English teachers. Hopefully, it can be a great help for the students to get rid of problems understanding English tenses. One example is that a teacher can apply a 'Small Talk' technique when teaching speaking. The teacher can start talking to the students by giving away an easy conversation topic that is full of using simple tenses. The simple conversation topics are about hobbies, future plans, dreams, past activities and story telling. While the students are talking to each other, the teacher must go around the class correcting instantly the wrong use of tenses by the students. Once the teacher corrected the mistakes, she should be extra cautious to do it, otherwise the student might lose his interest to learn the tenses again. This technique should be repeatedly applied in order to help the students get very familiar with English tenses used in their daily conversations.

Another technique to stimulate students' interest is called 'making topic'. In the speaking class, a teacher can use this technique focusing on the use of tenses. The 'making topic' technique is used by raising a topic to talk about in the class and it should be an easy topic to share to each student. Again, the teacher should gather information from the students who are busy talking about a particular topic and to make sure that the students are using the correct tenses. If mistakes are found, the teacher should hurriedly help them with the correct one. In this way, hopefully the students are enjoying the English class a lot more than that in the past.

The other technique to help students grow with their great interest to learn English tenses is using an audio-visual media. The media can be a 'Motion Video' like the media that can be found on the Internet "http://www.elihinkel.org/tips/tenses.htm" which explains all about English tenses. While the students are watching the video, the teacher is giving additional explanation where necessary. By using this media to teach English tenses, the students not only learn more easily but also keep them passionate to follow the class. It is because learning English with audio-visual media is definitely something new for the students.

The same thing is when learning tenses in the writing class, it is expected that the students will understand non only how to write well but also how to put down ideas in good manner. 
It means that the students will be asked to write starting from what the students are doing in that time, what the students will do in the future time, what the students did in the past time. After the writing task is completed, ask the students to put everything into practice such as what they have already written, the most important things that they have. In this way, the students have more chances to express their ideas orally and in the long run they will dare speak more in English both inside and outside schools. They will also grow with great confidence in speaking English, along with well-memorized tenses used in correct contexts of situation.

\section{CONCLUSION}

The main purpose of conducting this study is to know how good the tenth grade students of SMKN 2 BANGKALAN use the six English tenses in daily conversation. The interview was used to collect supporting data after observation was conducted. Observation was done to know the students' problems in English class, along with the solutions of the problems. A great number of students have problem using the English tenses, in particular the use of the six English tenses in daily conversations. It means that the use of the six English tenses in students' daily conversation was fairly poor and the students used mostly one tense in all their conversations. In their conversation, the students used simple present tense in all situations. That can be seen from students' conversation using only simple present tense in every situation. It happens due to various serious factors. One of them is having poor understanding about tenses in daily conversation. Sadly, the students were passive students. It means that the students almost never speak English with their classmates or with their English teacher. This phenomenon affects their fellow students' understanding of tenses during conversation activities. The difficulties in memorizing the formula of tenses, verb forms, time signal and auxiliary verbs are also a problem for the students. They have poor mastery of vocabularies and the quality in pronunciation was fairly poor, too. To solve all the problems, the students must try harder to study again about tenses and do a lot of practices daily.

The researchers received a one-single-surprising answer 'Studying' as soon as asking the students how to solve all their problem in learning tenses. However, that one-word answer does not reflect the true condition of the students' mastery of English tenses. In fact, they only knew a little about using the six tenses of English in particular. The students still have problem memorizing the verb forms, pattern of each tense, the formula and other supporting aspects in tenses. Based on the problems above, the teacher was encouraged to create new teaching techniques in learning tenses. The techniques are supposed to encourage the students to have more passions to learn English tenses in many ways. One technique is applied by making use of an audio-visual media. This technique was proven effective enough to generate the students' interest to keep up with the lesson. In short, the most important thing to learn English tenses for the students is a motivation. It helps them grow with everlasting understanding of the lessons.

\section{REFERENCES}

Brown, Douglas. (2000). Principles of Language Learning and Teaching $2^{\text {nd }}$ Edition. Cambridge: Longman. 
Cook Hirai, Debra L., Borrego, Irene, Garza, Emilio, and Kloock, Carlt. (2009). Academic Language/Literacy Strategies for Adolescents. New York: Taylor \& Francis eLibrary.

Gabor, Don. (2011). How to Start a Conversation and Make Friends. New York: Afiresid Ebook.

Harmer, Jeremy. (1998). How to teach English. London: Longman.

Khoiriyah. (2011). A Study on Students' Speaking Skill at Eleventh Grade of SMA Yayasan KH. Mohammad Holil Satria Sepulu Bangkalan in the 2010-2011.

Luoma, Sari. (2004). Assessing Speaking. New York: Cambridge University Pres.

Moran, Gabriel. (2008). Speaking of Teaching Lessons from History. United Kingdom: Lexington Books.

Pardiyono. (2004). Commmunicative Grammar Focus and Exercise for easier conversation and better assessment. Yogyakarta: Andi.

Richards, Jack C. (2002). Techniqueology in Language Teaching. Cambridge: Cambridge University Press.

Sugiyono. (2011). Metode Penelitian Kuantitatif Kualitatif dan R \&D. Bandung: Alfabeta. 